\title{
Robber Flies, Asilidae (Insecta: Diptera: Asilidae) ${ }^{1}$
}

\author{
E. M. Finn ${ }^{2}$
}

\section{Introduction}

The robber flies are an abundant and diverse family within the order Diptera that are known for their predatory behavior. Asilidae diversity can be attributed to their broad distribution; most species tend to occupy a selective niche. As their common name implies, robber flies have voracious appetites and feed on a vast array of other arthropods, which may help to maintain a healthy balance between insect populations in various habitats (Joern and Rudd 1982, Shurovnekov 1962). Asilidae adults attack wasps, bees, dragonflies, grasshoppers, other flies, and some spiders. Robber flies are particularly abundant in arid and sunny habitats, which are optimal conditions in which to observe their many morphs and behaviors.

\section{Description}

Asilidae are a family of true flies belonging to the superfamily Asiloidea within the suborder Brachycera. To date, there are approximately 6,750 described species of Asilidae distributed throughout the world (Geller-Grimm 2002). There are nearly 1,000 North American species of robber flies, with more than 100 species occurring in Florida. Loew was perhaps the most influential dipterist to

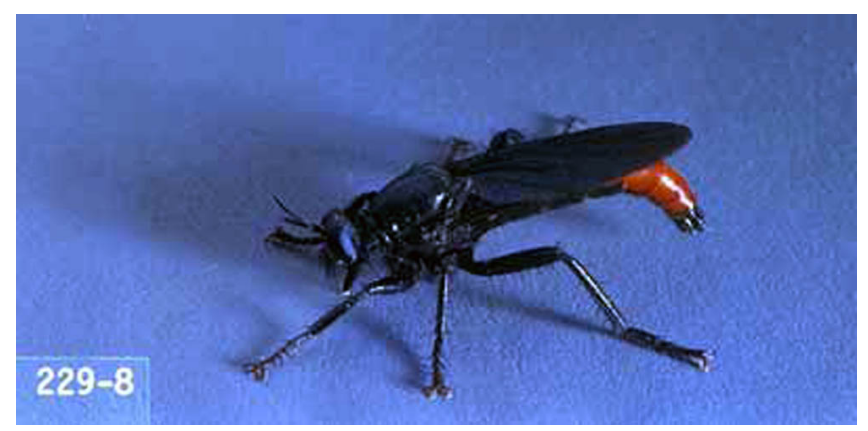

Figure 1. Adult Ospriocerus abdominalis Say, a robber fly. Credits: Ken Gray, Oregon State University

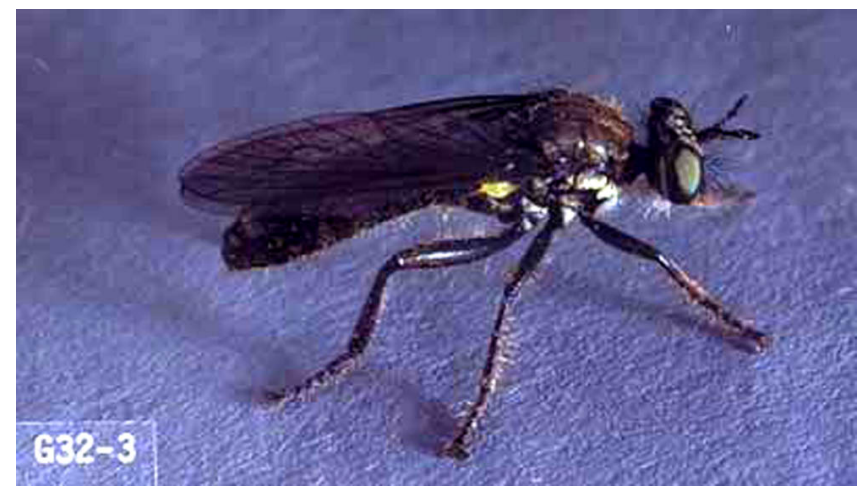

Figure 2. Adult Dioctria media Banks, a robber fly. Credits: Ken Gray, Oregon State University

contribute information to the study of robber flies, describing several species and more than 80 genera. Other mid-nineteenth century contributors include Macquart, Walker, Rondani, and Bigot. Later,

1. This document is EENY-281, one of a series of Featured Creatures from the Entomology and Nematology Department, Florida Cooperative Extension Service, Institute of Food and Agricultural Sciences, University of Florida. Published: January 2003. This document is also available on Featured Creatures Website at http://creatures.ifas.ufl.edu. Please visit the EDIS Website at http://edis.ifas.ufl.edu.

2. E. M. Finn, Entomology and Nematology Department, University of Florida, Gainesville, FL.

The Institute of Food and Agricultural Sciences (IFAS) is an Equal Employment Opportunity - Affirmative Action Employer authorized to provide research, educational information and other services only to individuals and institutions that function without regard to race, creed, color, religion, age, disability, sex, sexual orientation, marital status, national origin, political opinions or affiliations. For information on obtaining other extension publications, contact your county Cooperative Extension Service office. Florida Cooperative Extension Service / Institute of Food and Agricultural Sciences / University of Florida / Larry R. Arrington, Interim Dean 
dipterists in the 1900's became specialists of robber flies in particular locales, most notably Curran and Bromley in North America.

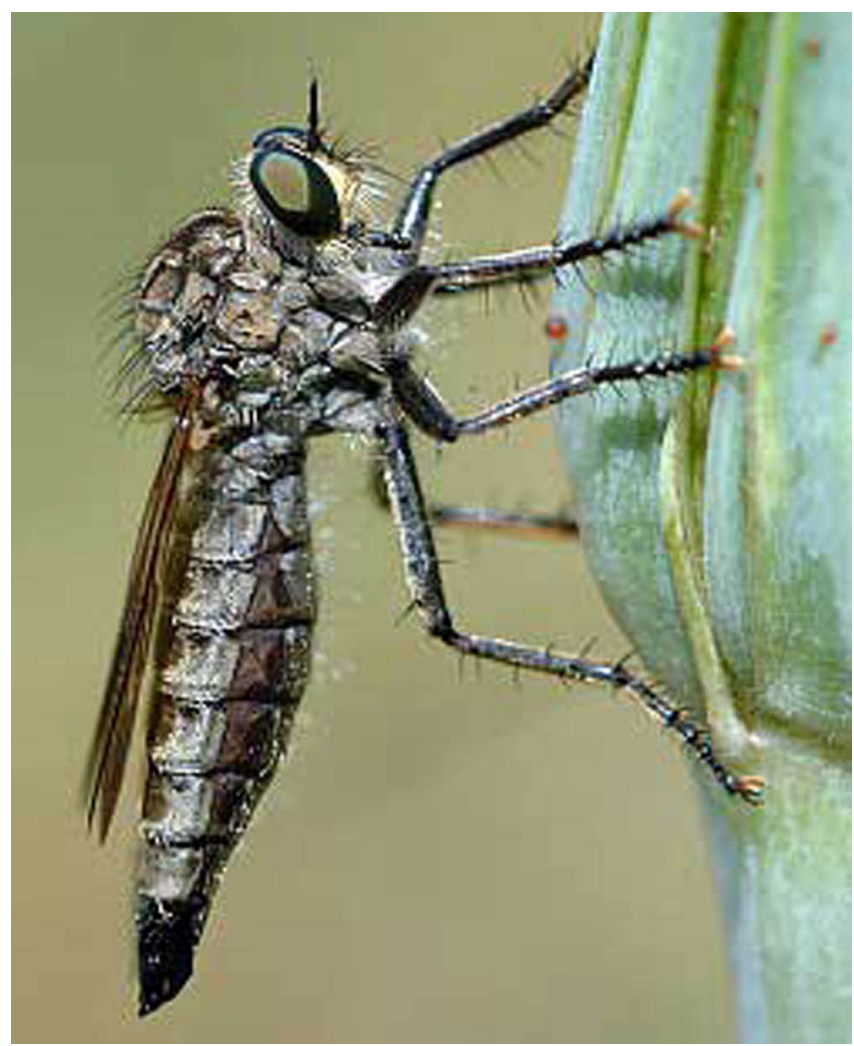

Figure 3. Adult female Dysmachus trigonus, a robber fly. Credits: Fritz Geller-Grimm, Museum Wiesbaden, Germany

All robber flies have a characteristic divot on top of the head, which is located between their especially prominent compound eyes. In general, adult Asilidae have an elongate body with a tapered abdomen. However, some species are stout and hairy, mimicking bumble bees, and still others may be slender and have a damsel fly appearance. Adults range in size from small $(3 \mathrm{~mm})$ to very large (over $50 \mathrm{~mm}$ ), averaging 9 to $15 \mathrm{~mm}$ in length (Wood 1981). Robber flies have long, strong legs that are bristled to aid in prey capture. Sexual dimorphisms are not extreme, although females tend to have slightly broader abdomens than males. Most robber flies have a brown, gray, or black coloration.

\section{Biology}

Female Asilidae deposit whitish-colored eggs on low-lying plants and grasses, or in crevices within soil, bark, or wood. Egg-laying habits depend on the species and their specific habitat; most species lay

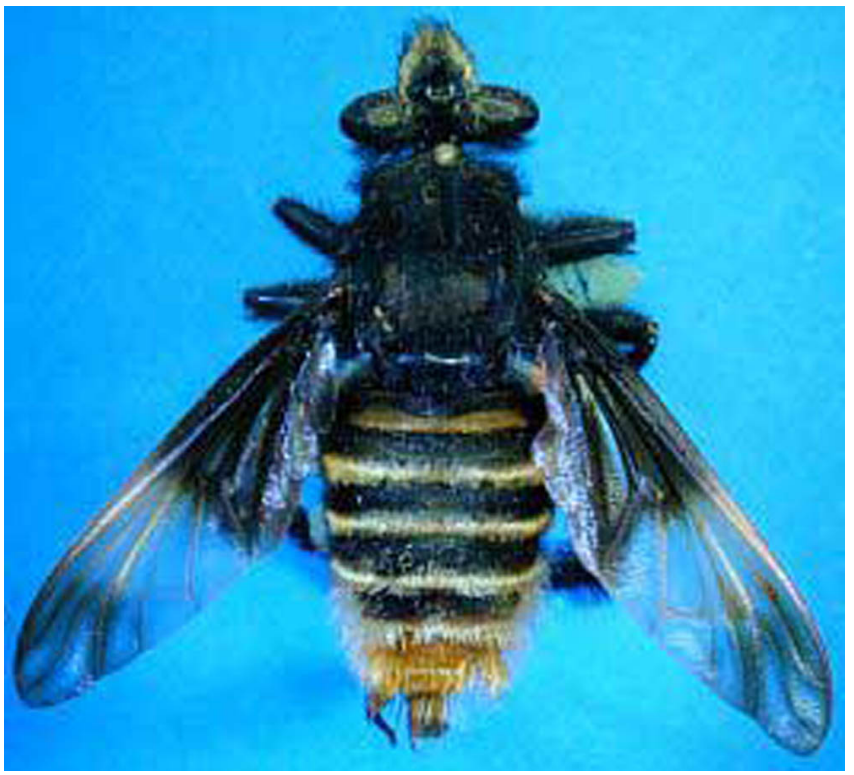

Figure 4. Adult Dasyllis haemorrhoa, a robber fly mimic of Euglossa dimidiata (Hymenoptera) in Brazil. Credits: Fritz Geller-Grimm, Museum Wiesbaden, Germany

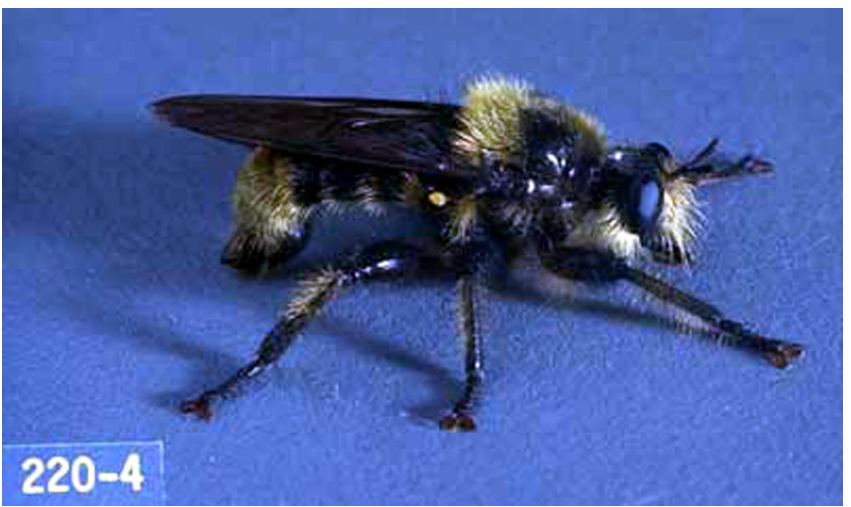

Figure 5. Adult Laphria sp., a robber fly that mimics a bumble bee. Credits: Ken Gray, Oregon State University

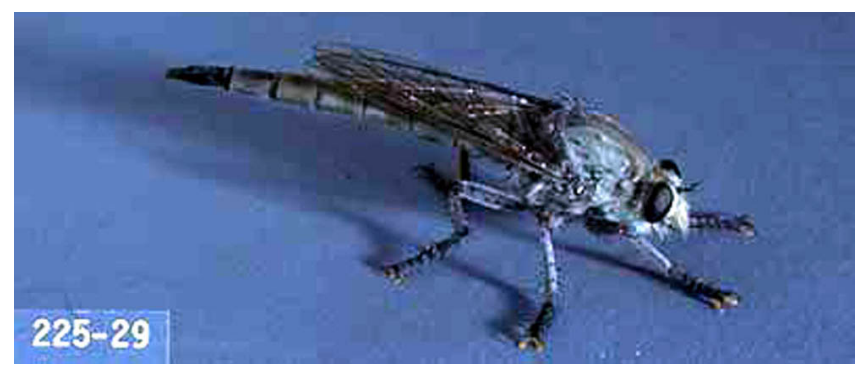

Figure 6. Adult Proctacanthus occidentalis Hine, a robber fly. Credits: Ken Gray, Oregon State University

their eggs in masses, which are then covered with a chalky protective coating. Robber fly larvae live in the soil or in various other decaying organic materials that occur in their environment. Larvae are also predacious, feeding on eggs, larvae, or other soft-bodied insects. Robber flies overwinter as larvae 
and pupate in the soil. Puparia migrate to the soil surface and emerge as adults, often leaving behind their pupal casing. Complete development ranges from one to three years, depending on species and environmental conditions. Theodor (1980) proposed that larval growth is accelerated in warmer regions and that many Asilidae species live no longer than one year.

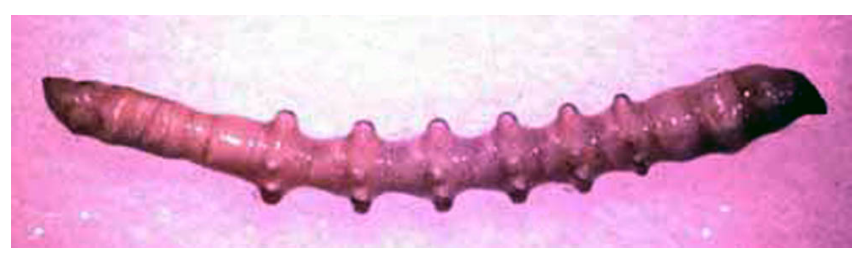

Figure 7. Larva of an unidentified laphriine robber fly. Credits: Stephen W. Bullington

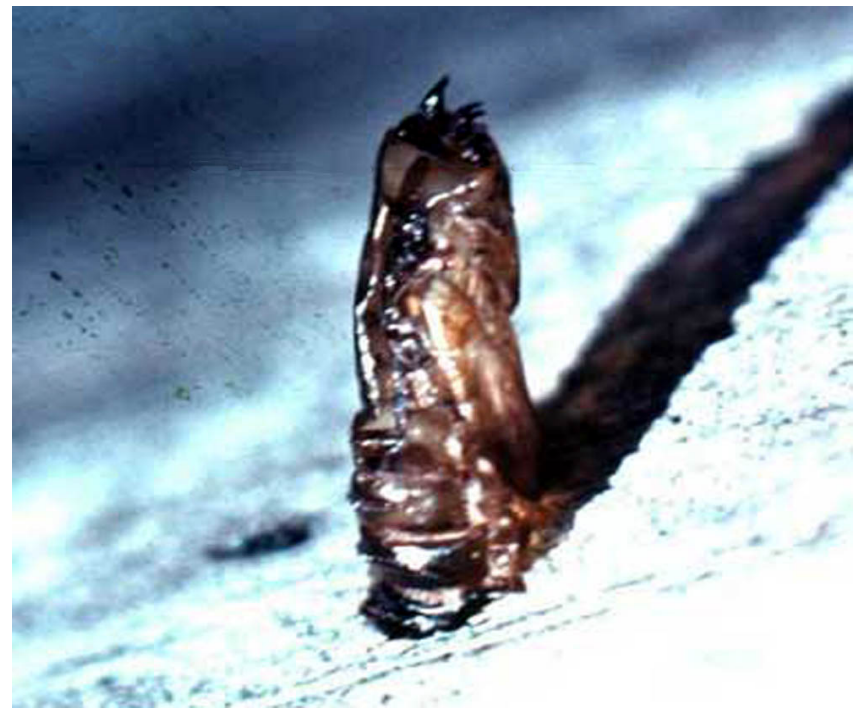

Figure 8. Exuviae of an unidentified laphriine robber fly. Credits: Stephen W. Bullington

\section{Behavior}

Robber flies are opportunistic predators, their diets often reflecting prey availability in a particular habitat. Shelly (1986) reported that of the nine Neotropical Asilidae species he studied, diet constituents were more than $85 \%$ composed of insects from the orders Diptera, Coleoptera, Hymenoptera, Homoptera, and Lepidoptera. Furthermore, larger species tended to consume a greater diversity of prey taxa. Robber flies generally establish a perching zone in which to locate potential prey. Perching height varies by species, but generally occurs in open, sunny locations. Asilidae seize their prey in flight and inject their victims with saliva containing neurotoxic and proteolytic enzymes. This injection, inflicted by their modified mouthparts (hypotharynx), rapidly immobilizes prey and digests bodily contents. The robber fly soon has access to a liquid meal, which is generally consumed upon returning to a perched position.

Robber flies exhibit minimal courtship behavior. Instead, the male pounces on the female much like an act of prey acquisition. Copulation is accomplished in a tail-to-tail fashion with the male and female genetalia interlocked. Flight is not completely inhibited during mating.

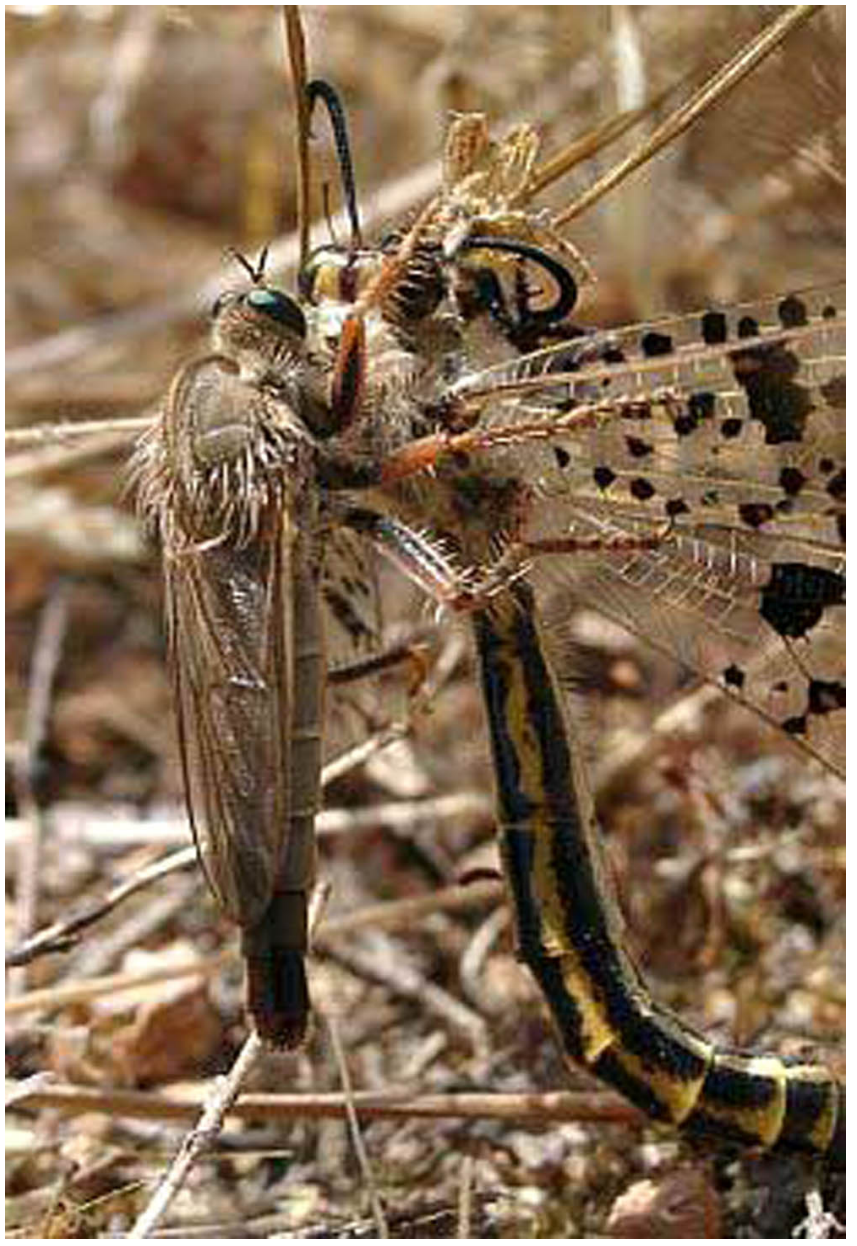

Figure 9. Robber fly, Stenopogon sp., with an antlion, Palpares libelluloides, prey. Credits: Mike Taylor

\section{Distribution}

The Asilidae enjoy a worldwide distribution, with certain groups occurring characteristically in certain regions (Hull 1962). For instance, the genera of Megapodinae are unique to the Neotropical region. Large island chains tend to encompass abundant asilid 


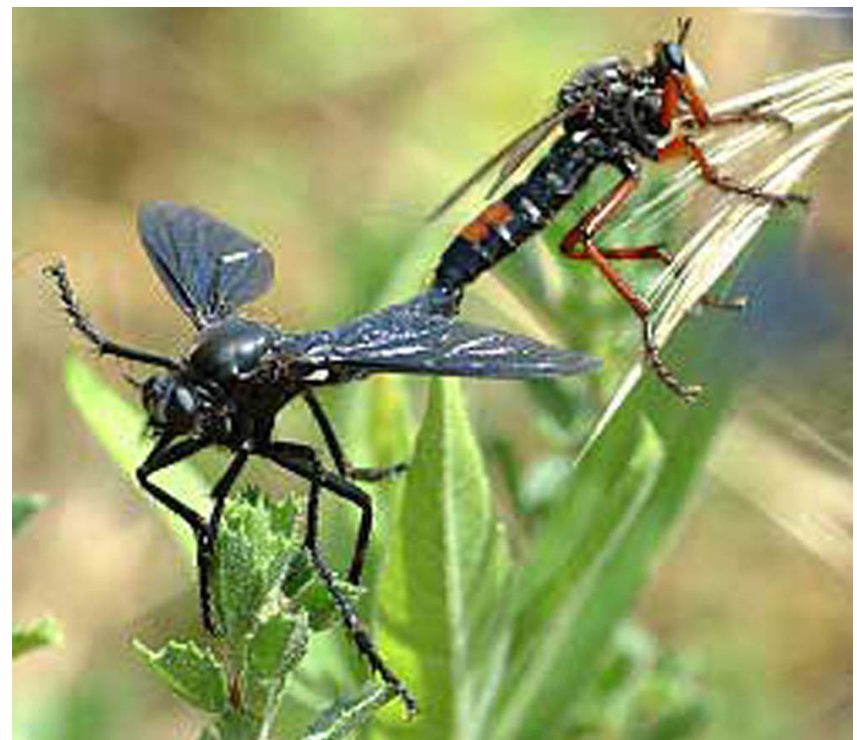

Figure 10. Mated pair of Dasypogon diadema. Credits: Fritz Geller-Grimm, Museum Wiesbaden, Germany

faunas, particularly those south of Asia. By contrast, smaller islands such as the Hawaiian chain have no endemic or introduced species (Hull 1962). The majority of robber fly species are found in dry, sandy conditions, as confirmed by the diversity of species found in such locales. Some species are well adapted to desert climates, where they are known to thermoregulate in response to temperature variations throughout the day (O'Neill et al. 1988, O'Neill and Kemp 1990). Few species occur in woodland areas, and those that do tend to aggregate along the edges, near grasslands. In Florida, all four subfamilies of Asilidae are present, including Asilinae, Dasypogoninae, Laphriinae, and Leptogastrinae. Within these subfamilies, the following genera are known to exist in Florida (Choate, unpublished manuscript) (See Table 1):

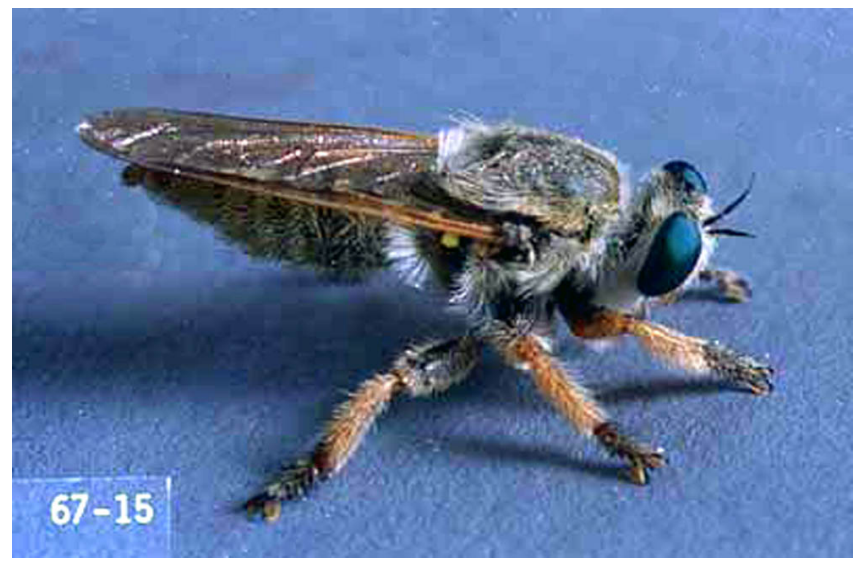

Figure 11. Adult Mallophorina sp., a robber fly. Credits: Ken Gray, Oregon State University

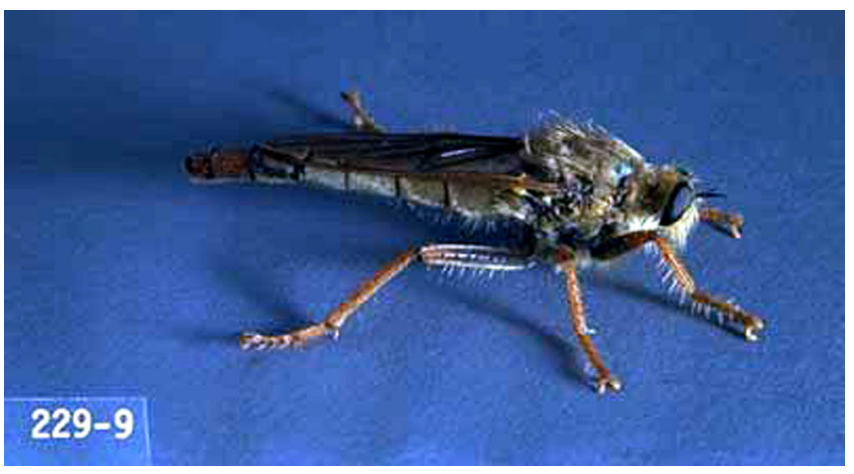

Figure 12. Adult Stenopogon sp., a robber fly. Credits: Ken Gray, Oregon State University

Table 1. Asilidae subfamilies

\begin{tabular}{|ll}
\hline \hline Asilinae & Nicocles (2) \\
Asilus (10) & Stenopogon (2) \\
Efferia (11) & Stichopogon (2) \\
Mallophora (5) & Taracticus (1) \\
Mallophorina (2) & \\
Neoitamus (1) & Laphriinae \\
Ommatius (2) & Andrenosoma (3) \\
Proctacanthus (8) & Atomosia (3) \\
Promachus (4) & Cerotainia (1) \\
Dasypogoninae & Lampria (2) \\
Ceraturgopsis (1) & Laphria (8) \\
Ceraturgus (1) & Orthogonis (1) \\
Cyrtopogon (1) & Pogonosoma (1) \\
Dioctria (3) & \\
Diogmites (7) & Leptogastrinae \\
Dizonias (1) & Apachekelos (1) \\
Heteropogon (1) & Beameromyia (2) \\
Holcocephala (2) & Leptogaster (6) \\
Holopogon (1) & Leptogaster (Psilonyx) (1) \\
Laphystia (2) & Psilonyx (1) \\
\hline
\end{tabular}

\section{Key to the Subfamilies of Florida Asilidae}

1. Marginal cell open .............. 2

1'. Marginal cell closed .............. 3

2. Palpi one-jointed; small, slender species; antennae with slender terminal arista . . . . . . Leptogastrinae 
2'. Palpi two-jointed; antennae with or without a thickened terminal style....... Dasypogoninae

3. Antennae with or without a terminal style, never a terminal arista; palpi two-jointed .... . . Laphriinae

3'. Antennae with slender terminal arista; palpi one-jointed ............. Asilinae

\section{Selected References}

Bromley SW. 1950. Florida Asilidae (Diptera) with descriptions of one new species. Annals of the Entomological Society of America 43: 227-239.

Bullington SW. (2001). The Laphriini pages. http://www.key-net.net/users/swb/Laphriini/ Laphriini.htm (15 July 2002).

Cannings RA. (1998). Robber flies (Insecta: Diptera: Asilidae). http://www.eman-rese.ca/eman/reports/publications/ 99_montane/robber_f/intro.html (15 July 2002).

Geller-Grimm F. (2002). Robber flies (Asilidae). http://www.geller-grimm.de/asilidae.htm (15 July 2002).

Hull FM. 1962. Robber flies of the world. Bulletin of the United States National Museum 224: 1-907.

Joern A, Rudd NT. 1982. Impact of predation by the robber fly Proctacanthus milbertii (Diptera: Asilidae) on grasshopper (Orthoptera: Acrididae) populations. Oecologia 55: 42-46.

Mahr S. 1999. Know your friends: robber flies. Midwest Biological Control News 6: 1-2.

O'Neill KM, Kemp WP, Johnson KA. 1988. Behavioral thermoregulation in three species of robber flies (Diptera: Asilidae: Efferia). Animal Behavior 39: 181-191.

O'Neill KM, Shelly TE. Body temperature regulation in desert robber flies (Diptera: Asilidae). Ecological Entomology 13: 419-428.

Shelly TE. 1986. Rates of prey consumption by Neotropical robber flies (Diptera: Asilidae).

Biotropica 18: 166-170.
Shurovnekov BG. 1962. Field entomophagous predators (Coleoptera, Carabidae, and Diptera, Asilidae) and factors determining their efficiency. Entomological Review 41: 476-485.

Theodor O. 1980. Diptera: Asilidae. Fauna Palestina: Insecta II. The Israel Academy of Sciences and Humanities, Jerusalem. 446 pp.

Wood GC. 1981. Asilidae. In: McAlpine JF, Peterson BV, Shewell GE, Teskey HJ, Vockeroth JR, Wood DM. (Eds.): Manual of Nearctic Diptera. Vol. 1 - Research Branch, Agriculture Canada, Monographs 27: 549-573; Ottawa. 